\title{
Trends In Critical Reading Skills Research In The Journal Of Indonesian Language and Literature Education In PPJB-SIP
}

\author{
Arif Setiawan $^{1 *}$, Musaffak ${ }^{2}$, Rosalin Ismayoeng Gusdian ${ }^{3}$ \\ Universitas Muhammadiyah Malang ${ }^{1,2,3}$ \\ \{arifsetiawan@umm.ac.id ${ }^{1}$ \}
}

\begin{abstract}
The 21st century requires that every individual has a critical ability to receive, process, and understand diverse information. This study aimed at answering the questions (1) what are the research profiles of critical reading skills from year to year? and (2) what are the profiles of the research subjects used to determine critical reading skills? The research method in this study was content analysis. The sources of the data in this study were 113 journals written in the PPJB-SIP website and database. This study's data were the results of the content analysis of research articles on critical reading skills. The instrument used in this study was a content analysis guideline. The results showed a number of critical reading skill studies conducted from 2011-2020 with the highest results in 2015-2017. Besides, the research subjects were dominated by undergraduate students. This research would give valuable information about critical reading skills profiles and become a basis to activate critical reading skills amid the digital information era.
\end{abstract}

Keywords: critical reading skills; journal of Indonesian language and literature education;, research profiles

\section{Introduction}

The 21 st century is marked by information sources' openness, globalization, and knowledge (Afandi, Junanto, \& Afriani, 2016; Wijaya, Sudjimat, \& Nyoto, 2016). One of the most prominent characteristics of the 21 st century is the change of civilization from the agrarian society to the industrial society that eventually leads to the information society (Afandi et al., 2016; Lestari, 2020). The transformation process in the society has brought about social and cultural changes (Afandi et al., 2016). Due to shifts in information sources from books to screens and changes from printed mass media to online mass media, it shows that the need for communication activities and the rapid flow of information also increases (Lestari, 2020). This condition is inevitable so that every community in the world needs to accept the irrepressible explosion of digital information (Sofwan \& Habibi, 2016; Syahminan, 2014). The data prove that the world has produced 2.5 quintillions of data in the forms of files, printed media, and digital media (Afandi et al., 2016). 
Proceeding of the International Seminar on Social Science, Humanities and Education (ISSHE) 2020

The explosion of digital information undoubtedly makes every individual more selective in sorting and critically reading sources of information (Muttaqiin, 2015; Putra, 2015). Reading critically every information that has been obtained is a mandatory thing that must be done (Hariyati, 2019), before sharing the information with other people (Diana, 2014). Through critical reading activities, it is expected that wrong information will not occur as it may result as a hoax. (Bafadhal \& Santoso, 2020). However, this condition has not been well realized in the Indonesian digital society (Afandi et al., 2016). It is proven by the Indonesians' low critical reading ability in receiving digital information included in messaging or news features in each gadget (Wijaya et al., 2016).

Concerning the significance of critical reading skills, several studies about critical reading skills have been carried out. Most of these studies investigated critical reading skills in education (Aryanta, Wendra, \& Artawan, 2014; Diana, 2014; Muttaqiin, 2015; Priyatni, 2014; Putra, 2015; Setiawan, 2013). However, a study that examines the profiles of critical reading skills on research findings that have been published in scientific articles, especially in Indonesian language and literature journals, has never been conducted. This research would give valuable information about the profiles of critical reading skills, as well as become a basis to activate critical reading skills amid the digital information era. This study aims to answer (1) what are the research profiles of critical reading skills from year to year? And (2) what are the profiles of the research subjects used to determine critical reading skills?

\section{Methods}

This study used a content analysis method that emphasized on the findings of various studies of critical reading skills published in Indonesian language and literature journals at PPJB-SIP. In this study, sources of data were 113 journals included in the Association of the Management of Language, Indonesian Literature and Teaching Journals (PPJB-SIP). All of the articles were listed on the PPJB-SIP website and database. Collection of the research data was carried out based on the results of the content analysis carried out in articles that discussed critical reading skills. This study's research instrument was a content analysis guideline that contained several aspects related to the points observed, as shown in Table 1. In this study, two main aspects were reviewed: (1 number of publications per year and (2) research subjects. The categories shown in Table 1 were adapted from Susetyarini \& Fauzi's (2020) research model. Each article was classified based on predetermined aspects. The decisions were based on the amount of information the author(s) shared in the abstract, methods, and discussion sections. Results of data analysis are presented in a formal method, that is, in chart of bar.

Table 1.Indicators for Content Analysis

\begin{tabular}{lllll}
\hline \multicolumn{1}{c}{ Aspect } & \multicolumn{3}{c}{ Category } \\
\hline Publication & 1.1 & 2010 & 1.6 & 2016 \\
Year & 1.2 & 2011 & 1.7 & 2017 \\
& 1.3 & 2012 & 1.8 & 2018 \\
& 1.4 & 2014 & 1.9 & 2019 \\
& 1.5 & 2015 & 1.10 & 2020 \\
\hline Research & 3.1 Junior high School Students Grade VII & 3.7 Undergraduate students \\
Subject & 3.2 Junior high School Students Grade VIII & 3.8 Postgraduate Students \\
& 3.3 Junior high School Students Grade IX & 3.9 Junior High School Teachers \\
\hline
\end{tabular}


Proceeding of the International Seminar on Social Science, Humanities and Education (ISSHE) 2020

$\begin{array}{ll}\text { 3.4 Senior high School Students Grade X } & \text { 3.10 Junior High School Teachers } \\ \text { 3.5 Senior high School Students Grade XI } & \\ \text { 3.6 Senior high School Students Grade XII } & \text { 3.11 Lecturers }\end{array}$

\section{Result and Discussion}

From the research results, two data sets were found, namely the year of publication and the research subject. Data from these two sources are described in Figure 1 and Figure 2.

\subsection{Publication Year}

The number of research on critical reading has occurred over a certain period. Figure 1 shows that the critical reading skill articles were initially found in 2011. The figure also displays that the studies on critical reading skills from 2010 to 2020 have not experienced any significant shifts from year to year. Besides, the number of critical reading articles fluctuated from 2011 to 2014. In the subsequent years between 2015 and 2017, however, the number of critical reading articles increased. Meanwhile, from 2018 to 2020, the number of research articles on critical reading skills has fluctuated with a slight decrease trend.

Many studies have been conducted on critical reading skills; this greatly affects the readiness to enter the digital era. It is based on the assumption that accuracy, thoroughness, and criticality are needed in accessing easily-obtained information in the digital era. (Afandi et al., 2016; Darmalaksana, Hambali, Masrur, \& Muhlas, 2020; Sofwan \& Habibi, 2016; Syahminan, 2014; Wijaya et al., 2016). The studies on critical reading skills can be used as evaluation material to improve critical reading activities or research in the future. Besides, research on critical reading skills can be carried out more intensively within the environment of education (Muttaqiin, 2015; Muttaqiin \& Sopandi, 2016), because education is at the forefront of preparing human resources who are ready to face the digital era (Afandi et al., 2016; Lestari, 2020).

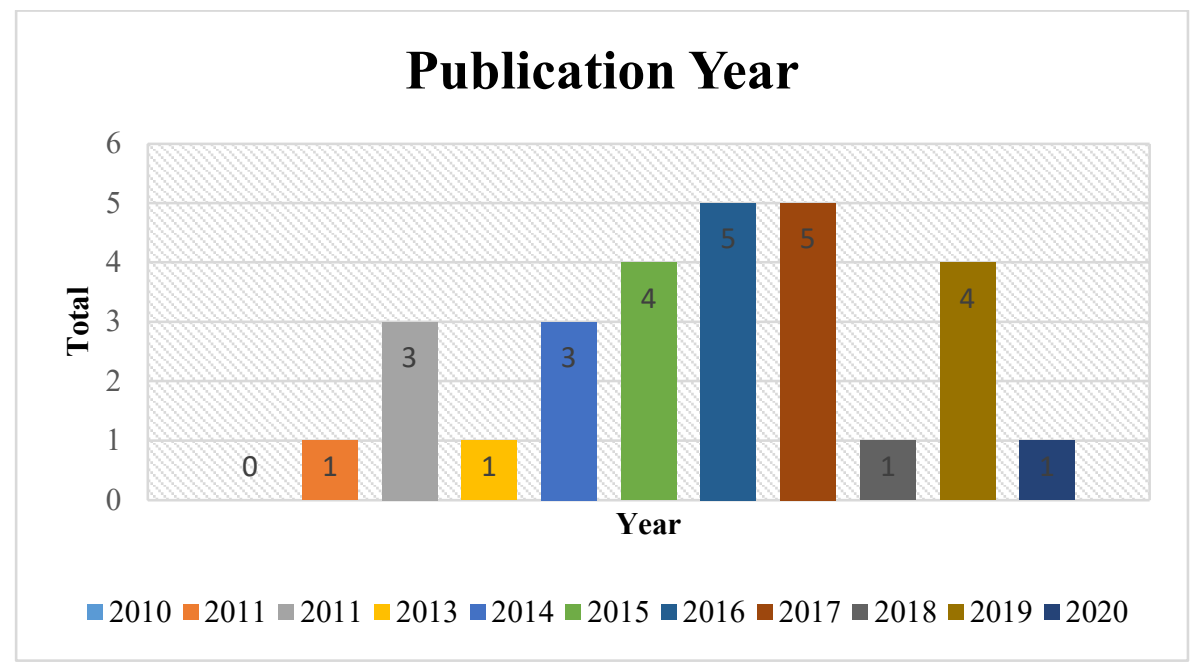

Figure 1. Publication Profiles of Critical Reading Skills Research in the Last 10 Years 


\subsection{Research Subjects}

The research subjects on critical reading skill articles are shown in Figure 2. As shown in the Figure 2, the most dominant research subjects are seventh grade students of junior high school and undergraduate students; then, followed by ninth grade high school students, grade eleventh XI high school students, and eigth grade junior high school students.

Figure 2 shows that the most frequent research subjects in critical reading research articles are undergraduate students, followed by junior high and high school students. It indicates that the research subjects selected in applying critical thinking skills are undergraduate students who are more prepared. It further reinforces the notion that critical reading skills are complex reading activities and require high-level reading comprehension skills (Priyatni, 2014). In addition, critical reading skills require a high level of thinking and reasoning that is oriented to the development of the reader's thinking, morals and emotions (Lestari, 2020). It is in line with the idea that undergraduate students are human resources who need to be more prepared to face the digital era (Afandi et al., 2016; Wijaya et al., 2016). Also, Undergraduate students are cognitively, morally, and emotionally mature in understanding the reading texts (Ardiasri, Priyatni, \& Andajani, 2017; Hariyati, 2019; Priyatni, 2014; Riadi, 2015). Hence, preparing undergraduate students as agents of change and human resources who can compete in the digital era is an absolute and non-negotiable thing.

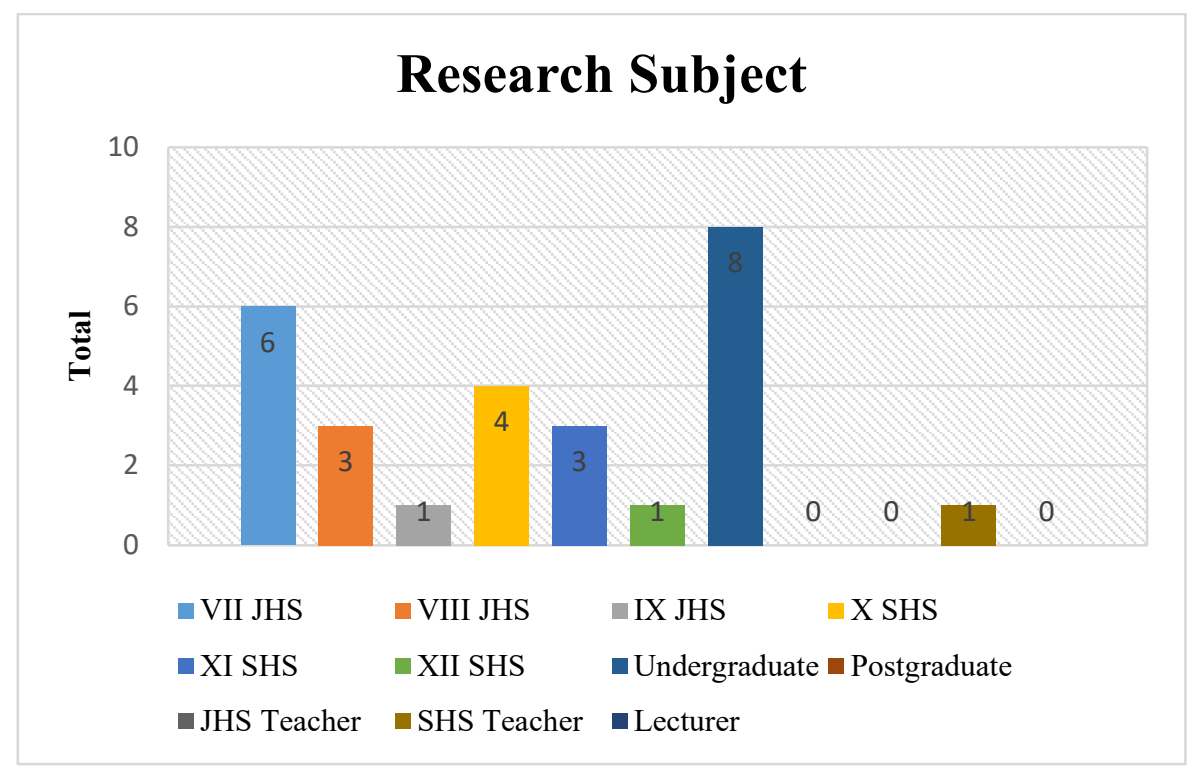

Figure 2. Research Subjects of Critical Reading Skill Articles

\section{Conclusion}

According to the research findings, the research profiles of critical reading skills have been carried out from 2011 to 2020 . In the period 2011 to 2014 and 2018 to 2020 there were ups and downs in the publication of the research articles on critical reading skills. Meanwhile, the number of critical reading skills research showed an increase during the period of 2015 to 
2017. The most dominant research subjects used in research articles on critical reading skills are undergraduate students. This condition is in line with their level of cognitive, moral, and emotional maturity in understanding reading texts. This research will provide invaluable information about the profiles of critical reading skills, as well as become a basis for activating critical reading skills in the midst of digital information.

\section{References}

[1] Afandi, A., Junanto, T., \& Afriani, R. (2016). Implementasi digital-age literacy dalam pendidikan abad 21 di Indonesia. Paper presented at the Seminar Nasional Pendidikan Sains VI 2016.

[2] Ardiasri, A., Priyatni, E. T., \& Andajani, K. (2017). Bahan ajar membaca kritiskreatif teks eksposisi berbasis isu lingkungan hidup. Jurnal Pendidikan: Teori, Penelitian, dan Pengembangan, 2(10), 1416-1424.

[3] Aryanta, I. K. A., Wendra, I. W., \& Artawan, G. (2014). Penggunaan teknik 5w+1h untuk meningkatkan kemampuan memahami unsur intrinsik cerpen melalui membaca kritis di kelas VII C SMP Negeri 3 Singaraja. Jurnal Pendidikan Bahasa dan Sastra Indonesia Undiksha, 2(1), 1-12.

[4] Bafadhal, O. M., \& Santoso, A. D. (2020). Memetakan pesan hoaks berita covid-19 di Indonesia lintas kategori, sumber, dan jenis disinformasi. Bricolage: Jurnal Magister Ilmu Komunikasi, 6(02), 235-249.

[5] Darmalaksana, W., Hambali, R., Masrur, A., \& Muhlas, M. (2020). Analisis pembelajaran online masa wh pandemic covid-19 sebagai tantangan pemimpin digital abad 21. (Karya Tulis Ilmiah (KTI) Masa Work From Home (WFH) Covid-19 UIN Sunan Gunung Djati Bandung), UIN Sunan Gunung Djati Bandung, Bandung

[6] Diana, P. Z. (2014). Teknik membaca SQ3R dalam membaca kritis untuk penguatan pendidikan karakter di perguruan tinggi. CARAKA, 1(1), 31-40.

[7] Hariyati, N. R. (2019). Implementasi ASCO (analyzing, solving problems, and comparing) terhadap pembelajaran membaca kritis. LITERASI (Jurnal Ilmu Pendidikan), 10(2), 92-98.

[8] Lestari, Z. W. (2020). Analisis membaca mahasiswa dalam upaya pengembangan model ajar membaca kritis. Metalingua, 18(1), 187-198.

[9] Muttaqiin, A. (2015). Hubungan antara kemampuan membaca kritis dalam pembelajaran penemuan dan kemampuan berpikir kritis siswa. Edusentris, 2(2), 116125.

[10] Muttaqiin, A., \& Sopandi, W. (2016). Pengaruh model discovery learning dengan sisipan membaca kritis terhadap kemampuan berpikir kritis siswa. EDUSAINS, 8(1), 57-65.

[11] Priyatni, E. T. (2014). Pengembangan bahan ajar membaca kritis berbasis intervensi responsif. LITERA, 13(1), 1-13.

[12] Putra, D. A. K. (2015). Keterampilan membaca kritis pada mahasiswa jurusan Perbankan Syariah semester IV Fakultas Syariah dan Hukum, UIN Syarif Hidayatullah Jakarta. Dialektika: Jurnal Bahasa, Sastra, dan Pendidikan Bahasa dan Sastra Indonesia, 2(1), 77-88.

[13] Riadi, B. (2015). Kemampuan membaca kritis dengan menggunakan teknik SQ3R Mahasiswa Program Studi Pendidikan Bahasa dan Sastra Indonesia. AKSARA: Jurnal Bahasa dan Sastra, 16(2), 137-144. 
Proceeding of the International Seminar on Social Science, Humanities and Education (ISSHE) 2020

[14] Setiawan, A. (2013). Pengaruh penggunaan strategi katalis untuk meningkatkan kemampuan membaca kritis siswa kelas X MA Muhammadiyah 1 Malang. (Master), Universitas Negeri Malang Malang

[15] Sofwan, M., \& Habibi, A. (2016). Problematika dunia pendidikan Islam abad 21 dan tantangan pondok pesantren di Jambi. Jurnal Kependidikan: Penelitian Inovasi Pembelajaran, 46(2), 271-280.

[16] Susetyarini, E., \& Fauzi, A. (2020). Trend of critical thinking skill researches in biology education journals across Indonesia: from Research Design to Data Analysis. International Journal of Instruction, 13(1), 535-550.

[17] Syahminan, S. (2014). Modernisasi sistem pendidikan islam di indonesia pada Abad 21. Jurnal Ilmiah Peuradeun, 2(2), 235-260.

[18] Wijaya, E. Y., Sudjimat, D. A., \& Nyoto, A. (2016). Transformasi pendidikan abad 21 sebagai tuntutan pengembangan sumber daya manusia di era global. Paper presented at the Prosiding Seminar Nasional Pendidikan Matematika, Malang 